\title{
ЛИТЕРАТУРОВЕДЕНИЕ
}

\author{
УДК $821.581 / 131.1$
}

Ileana Di Nallo

\section{HUANG ZUOLIN AND ITALIAN COMMEDIA DELLARTE: AN EXPERIMENTAL STUDY IN THE CONCEPTION OF XIEYI THEATRE}

\author{
‘Carlo Bo’ University of Urbino, Via Aurelio Saffi, 2, 61029 Urbino PU, ITALY
}

Italian Commedia dell'arte was part of Huang Zuolin's studies aimed at the articulation of his xieyi (写意) concept of theatre. In the Sixties, when Chinese dramas were performed according to the standards of revolutionary realism and Stanislavsky's method, Huang Zuolin endeavoured to create a new method which supported the ideology of socialist China as well as maintaining the essence of national culture. Huang merged Western theatre with traditional Chinese theatre, focusing not only on Brecht, Stanislavsky and Beijing Opera, but also on Commedia dell'Arte in order to improve Chinese huaju artistic forms. The aim of this paper is to illustrate Huang Zuolin's study of Italian improvised theatre and his comparative work with Chinese traditional theatre in order to create an alternative to Stanislavsky's method and to promote the renovation of Chinese theatre. This paper will focus on how Huang traces the history of Commedia dell'Arte and its importance for the development of modern realistic theatre worldwide. Huang read Commedia dell'Arte as the origin of modern European theatre and connected it to Stanislavsky, who had an important ideological value for Chinese revolutionary theatre. In this way Huang directly linked Commedia dell'arte to Chinese theatre and included it among the artistic forms supported by the Chinese Government. This paper will ultimately illustrate how Huang compared Commedia dellarte to Beijing Opera, how he connected it to Chinese tradition and how he suggested employing Italian theatre to improve Chinese comic theatre techniques. Refs 15.

Keywords: Chinese theatre, intercultural studies, intercultural theatre, Chinese reception of Italian theatre.

\section{ХУАН ЦЗОЛИНЬ И ИТАЛЬЯНСКАЯ КОМЕДИЯ ДЕЛЬ АРТЕ: ЭКСПЕРИМЕНТАЛЬНЫЙ ПОИСК В КОНЦЕПЦИИ ТЕАТРА СИЕИ}

Илеана Ди Налло

«Карло Бо» Университет Урбино, Италия, 61029, Урбино PU, ул. Аурелио Саффи, 2

Весь XX в. китайские интеллектуальные круги волновала и продолжает волновать в настоящее время проблема поисков теоретических основ для дальнейшего развития театрального искусства в своей стране. Эти поиски обусловлены сложным комплексом причин, к которым можно отнести происходившие в стране серьезные социально-политические и экономические изменения, постоянно растущее национальное самосознание и гордость за накопленное богататейшее культурное наследие, стремление заявить о самобытности китайской культуры и вместе с тем о включенности ее на ведущих ролях в мировой культурный процесс. Китайские театроведы за это время предложили немало оригинальных идей, которые привлекают к себе внимание творческой элиты Китая, активно применяются и способствуют достижению

(c) Санкт-Петербургский государственный университет, 2017 
в культурной жизни значительных успехов. В ряду этих идей видное место по праву занимают теоретические наработки Хуан Цзолиня.

Статья посвящена драматургическим концепциям Хуан Цзолиня (1906-1994) - одного из крупнейших китайских режиссеров, драматургов и теоретиков современного театра. Получивший образование на Западе, Хуан Цзолинь занимался синтезом традиционного китайского театра и европейской драматургии.

Обращение Хуан Цзолиня в начале 1960-х годов к опыту итальянской комедии дель арте является малоизвестным фактом, который подробно рассматривается в данной статье. В исследовании выявляются мотивы, побудившие Хуан Цзолиня обратиться к комедии масок в условиях «революционизации» китайского театра, а также проводится сравнительный анализ амплуа пекинской музыкальной драмы и комедии дель арте, показаны особенности восприятия итальянской драматургии в Китае. Библиогр. 15 назв.

Ключевые слова: китайский театр, межкультурные исследования, межкультурный театр, восприятие итальянского театра китайским обществом.

Huang Zuolin's main contribution to the evolution of Chinese theatre is his theory of xieyi concept of theatre. It is known that he began his research on a new concept of Chinese modern theatre in the Sixties and, after the Cultural Revolution, he continued his work during the Eighties. The word xieyi 写意 was translated into English as "symbolic" in the Eighties but before this translation Huang Zuolin often used the English word "essential", because he put together (and at the same time compared) the two concepts of 'realistic' (xieshi 写实) of Western theatre and “essentialism” xieyi 写意 of Chinese traditional theatre [1, p.315].

Huang Zuolin's theory of xieyi xiju guan 写意戏剧观 (a "symbolic concept of theatre") was gradually developed through a long and complex process of studies that he included in his work Wo yu xieyi xiju guan 我与写意戏剧观 (Me and the symbolic concept of theatre). He aimed at finding a Chinese way for huaju contemporary theatre which, according to his words, would be a synthesis, or “zonghe 综合” [1, p. 4] "that results from the inevitable impact of Chinese and Western cultures" [1, p.4]. In his "synthesis" he 'reelaborated' and merged the theatre theories of three important drama practitioner, i.e. Mei Lanfang, Brecht and Stanislavsky.

In his research, Huang Zuolin studied other theatre forms as well, such as Italian Commedia dell'Arte (Italian improvised comic theatre). His study can be found in the article “Yidali jixing xiju” 意大利即兴喜剧 [2]. This is the publication of Huang Zuolin's speech at a Conference in Shanghai in 1961. He spoke in front of the Shanghai "Farce" Company (Shanghai Huaji xi 上海滑稽戏), but the specific date and place are not known. However, the main purpose of his study is clear, as confirmed not only by Huang Zuolin himself but also by the words of other scholars, such as Yu Weijie (余维杰), who stated:

[he introduced Italian improvised theatre to Shanghai Farce actors [...] he wanted to broaden Chinese theatre horizons and he turned to Brecht's theatre and Chinese tradition, but he especially wanted to use Italian Commedia dell'Arte and Goldoni's theatre to oppose the hegemony of Stanislavky's method] [4, p. 251]

According to Yu Weijie, Huang Zuolin aimed at introducing a new theatre method, an alternative to Stanislavsky's method, in order to offer a valid inspiration for the development of contemporary Chinese comic theatre's techniques.

According to other scholars' theories, such as Rossella Ferrari [5] and Chen Xiaomei (陈小眉, 1954 -) [6], it is possible to state that Huang Zuolin's approach in the introduction of Commedia dell'arte was similar to the one he had in the introduction of Brecht's 
theatre into the Chinese context. This study is based on the above mantioned theories in order to understand Huang's interpretation of Commedia dellarte.

Firstly, this paper aims at illustrating how Huang Zuolin introduced Italian Commedia dell'Arte and how he made this choice for a specific purpose. He chose Italian improvised theatre not only for its undeniable importance in the evolution of modern European theatre, but also because it was particularly suitable to be accepted by the Chinese audience and theatre experts. Huang Zuolin believed that Italian Commedia dell'Arte had something in common with both Stanislavsky's realistic theatre and Chinese traditional theatre, which is why he also believed Italian theatre was suitable for his theory of xieyi theatre.

Secondly, the paper aims at illustrating how Huang Zuolin conducted his research on Commedia dell'Arte with a double purpose. On the one hand, he used a utilitarian approach in order to improve Chinese comic theatre techniques. On the other hand, he needed to legitimate his choice in order to endorse and convey his theory into the Chinese cultural context. Huang Zuolin, in order to learn from Commedia dell'Arte experience, studied its most important creative and technical aspects and tried to merge it in his research of xieyi theatre. He chose to stress some particular aspects of Commedia dell'Arte that could be useful in supporting his theory.

Huang Zuolin argued that Chinese actors had to consider Commedia dell'Arte techniques as an important example to follow. He then explained that through the investigation of Italian comic theatre he could elaborate the "twelve artistic rules". These rules could be useful in comedy performance and should be followed by comic actors in their practice and training. They could be considered a practical foundation for starting a new path of artistic technique development in Chinese comic theatre.

The rules are:

1. 真真假假, 虽假犹真。True or false, even if false, act as if true.

2. 颠颠倒倒, 不失平衡。 to turn upside-down, do not lose balance.

3. 罗罗苏苏, 干净利落。Verbosity, smooth and clean.

4. 吵吵闹闹, 不落俗套。Sounds and noise, unconventional.

5. 插科打诨, 掌握分寸。Gags and jokes, do not go too far.

6. 巧合误会, 不忘哲理。Coincidental misunderstandings, never forget moral values

7. 旁敲侧击, 一针见血。Attack by innuendo, hit the nail on the head

8. 夸张许可, 不得过火。 Exaggeration is allowed, but without going beyond limits

9. 冷嘲热讽, 分清敌我。Biting sarcasm, distinguish enemies from us

10. 即兴发挥, 不离主题。Bring into play improvised acting, do not go far from the main subject

11. 情理之中, 意料之外。Within reason, beyond the expected

12. 继承传统, 不离生活。Inherit tradition, but do not go too far from actual life. $[2$, p. 301]

As evidence of Huang's utilitarian approach, some of them are pragmatic rules and stressed the importance of a realistic way of acting: the importance of body movements, sounds, wording and improvised acting (numbers 1-2-3-4-10). Other rules are more 
"ideological" - they stressed the importance of criticizing "enemies" through sarcasm (no. 9), of moral values and moderation even in comic theatre (no. 6 and 8) and so on. It is, in all cases, a list of practical suggestions that Huang Zuolin wanted Chinese comic actors to use when training, to improve their acting and to add something new.

In those years, Stanislavsky's method was the main acting method in Chinese huaju performances. Huang Zuolin, although never opposed to Stanislavsky's theatre, tried very hard to enhance Chinese theatre forms and theories and, in particular, to bring "Chineseness" back and make it part of huaju theatre. This was possible by borrowing techniques and values from Chinese classical theatre, by elaborating and integrating them with Stanislavsky's and other theatre techniques in order to create a new method.

Huang Zuolin was aware of the ideological role of Stanislavsky's theory in Chinese theatre. It is known that some years before the establishment of the People's Republic of China (1949), the realistic trend in theatre intensified [7]. Along with the spreading of Marxism ideology and political affinity to the Soviet Union, Stanislavsky's method was introduced into China and became popular in its interpretation connected to socialistic Realism theory. Chinese critique attributed a strong ideological value to Stanislavsky's method and it was identified as "the most suitable artistic method to be used" [8, p. 204] in the creation of new revolutionary theatre performances. "Stanislavsky's method was read according to the Chinese socialist ideology of the time" [5, p. 33] and became almost the only performing methodology on Chinese stages. The introduction of something different was likely to be a difficult operation, so Huang Zuolin first attempted to legitimate his choice of Commedia dell'Arte, stressing the connection between it and Stanislavsky's theatre, in order to make Italian Commedia dell'Arte permitted in Chinese ideology.

Huang pointed out that the greatest theatre personalities in the world had been directly influenced by Commedia dell'Arte [1, p. 284]. He stated that Commedia dell'Arte can be seen as the origin of modern realistic theatre - the theatre of Goldoni, Shakespeare and Stanislavsky all originated from it:

[。。］它影响了莎士比亚, 直接影响了莫里哀、哥尔多尼、甚至于卓别 林, 还影响了高尔基、高尔基又影响了斯坦尼斯拉夫斯基。它不是凭空而来, 也是继承了希腊、罗马、中世纪的即兴喜剧。从希腊-一罗马一一即兴喜剧—— 莎士比亚——哥尔多尼一一卓别林一一高尔基——斯坦尼斯拉夫斯基。 [2, p. 285]

[Shakespeare was influenced by it, Molière, Goldoni - even Charlie Chaplin - received its direct impact and then influenced Gorkij, who influenced Stanislavskij. It was not groundless and it also inherited Greek, Roman and medieval improvised comedy. From Greece - Rome - improvised comedy - Shakespeare - Goldoni - Chaplin Gorkij - Stanislavskij.]

Huang highlighted the historical continuity and the direct link from Commedia dell'Arte to Stanislavsky. By making a direct connection with Stanislavsky's theatre, Huang wanted to reveal how Italian Commedia dell'Arte could have an important role in the evolution of contemporary Chinese theatre. These words could support the legitimation and the validity of Huang's choice of Italian theatre in order to persuade Chinese theatre experts of his concept.

He then revealed when exactly Stanislavsky decided to employ Commedia dellarte features in his theatre practice: 
1910年高尔基患肺结核到意大利南部养病, 让传统的即兴喜剧迷住了, 当即写 信给斯坦尼斯拉夫斯基，让他来意大利：“我找到了好东西....... ” [。。。] 1912年斯氏去意大利观摩后回来开办的莫斯科艺术剧院第一期学馆, 就运用了 很多即兴喜剧的原则教学。如: 形体行动的训练-一亚剧; 默诵台词的自由走 动-一即兴表演, 所以不能把即兴喜剧看作是三百年前历史的东西, 而是表演 上的一种创作方法。[2, p. 286]

[In 1910, Gorkij contracted tuberculosis and went to southern Italy to recover, he was fascinated by traditional improvised comedy and immediately wrote to Stanislavskij, telling him to come to Italy: "I have found something good..." [...] In 1912 Stanislavskij, after returning from Italy, started the first session of Moscow Art Theatre and he used many principles of improvised comedy teaching, such as: physical training action pantomime; free movements during silent acting lines - improvised performance. So it is not possible to consider improvised comedy as something belonging to three hundred years ago, but a creative method of performance]

The last words of the above statement also reveal Huang Zuolin's utilitarian approach to Italian improvised theatre: he encouraged Chinese experts and intellectuals, such as Zhou Yang (周扬, 1908-1989), who was at the conference in Shanghai hold by Huang in 1961 in front of the Shanghai Farce Company, to take this Italian method into consideration like Stanislavsky had some decades earlier.

Huang also stressed which element of Commedia dell'Arte could be suitable for the Chinese revolutionary theatre concept. e.g. origins from ordinary people, its opposition to courtly theatre, the importance of characters that represent people from lower social classes, the depiction of people's daily lives and the importance of gestures and pantomime.

In the depiction of the historical background of Commedia dell'Arte, Huang Zuolin appreciated the direct connection between this style of theatre and Renaissance movement and the development of a "modern", illuminist concept of the world that was opposed to the medieval and catholic obscurantism of the previous era:

文艺复兴在意大利展开，原因是反对中世纪的教会压迫，它以禁欲主义控制了 人的思想和发展, 而文艺复兴的信条是针锋相对的 [。。。] 在当时世界观是 积极的。经济情况: 封建大地主的没落, 新兴资产阶级的兴起 [。。。] 意大 利是欧亚贸易的必经之道, 所以商业兴盛, 发展了很多城市。[2, p. 285]

[Renaissance developed in Italy in opposition to the oppressive system of the Medieval church, which controlled people's thoughts and development with asceticism, whereas the Renaissance creed was diagonally opposed to it [...] its view of the world was a positive one. Economic situation: decline of feudal landowners, the rise of a new bourgeoisie [...] Italy was an important trade route in Europe so the economy flourished and many cities developed.]

Huang Zuolin went on and depicted different styles of theatre in Italy in the $15^{\text {th }}$ century and paid particular attention to the opposition between "courtly theatre" and "folk theatre", stressing that Commedia dell'Arte was part of the latter:

当时的戏剧有两种：（1）宫殿戏剧（也称书斋戏剧）接过希腊、罗马的戏剧遗 产, 在宫廷演出, 说拉丁文, 是一种没有生命, 为艺术而艺术、与世隔绝的戏 
剧。（2）民间戏剧：接触、反映人民，创作的源泉来自生活，充满了生命力。 正象列宁所说: “每个民族都有两种文化，一种是宫廷的抄袭的没有生命力的， 另一种是民间......”意大利的即兴喜剧正是如此, 在当时最为广大人民所喜爱 [。。 0$][2$, p. 285]

[At that time there were two types of theatre: 1) Courtly theatre (also called learned theatre or "chamber" theatre), which was influenced by Greek and Roman theatre, was performed in Royal courts and was in Latin, it was a non-vital, art-for-art's sake, isolated-from-the-world kind of theatre. 2) folk or popular theatre: it reflected and was in touch with ordinary people, its creative source was real life and it was full of vitality. Exactly as Lenin said: "Every Nation has two cultures, one, from the imperial court, is plagiaristic and without vitality, the other is popular..." This is exactly the case of Italian Improvised theatre, the most favourite by the people [...]

It is possible to see similarities with some ideas of Chinese revolutionary theatre. Commedia dell'Arte, like Chinese revolutionary theatre, was a popular artistic form, it was vivid, "reflected" people's life and was inspired by the daily life of common people.

Chinese revolutionary theatre was based on Mao's 1942 Talks at Yan'an Forum on Literature and Art principles: according to the "popularization" of art and literature, revolutionary theatre must base its stories on ordinary people's lives:

[...] Our specialists are not only for the cadres, but also, and indeed chiefly, for the masses. [...] Our specialists in drama should pay attention to the small troupes in the army and the villages. Our specialists in music should pay attention to the songs of the masses. [...] All these comrades should make close contact with comrades engaged in the work of popularizing literature and art among the masses. On the one hand, they should help and guide the popularizers, and on the other, they should learn from these comrades and, through them, draw nourishment from the masses to replenish and enrich themselves so that their specialities do not become "ivory towers", detached from the masses and from reality and devoid of content or life. [...] [9, p. 24-25]

Huang Zuolin was aware of the importance of these words and principles, so highlighting the popular origin of Commedia dell'Arte would have supported the establishment of an affinity between revolutionary theatre and Italian improvised theatre, in addition to encouraging Chinese reception of Italian Commedia dell'Arte.

In order to make Commedia dell'arte familiar to Chinese intellectuals and make the integration into the Chinese theatre context possible, Huang Zuolin explained Commedia dellarte features also using Chinese traditional theatre standards and highlighted some extraordinary common points. The illustration of similarities between the two systems gave the definitive proof of suitability to its research for a xieyi theatre. He created empathy and made an interesting intercultural point of communication between the two artistic worlds, comparing the Chinese and the Italian one. Thanks to these similarities he identified Italian improvised theatre as a useful system for Chinese contemporary comic theatre. Chinese actors would not have to employ something 'alien' to their own culture, but something they felt familiar with in their cultural terms.

Huang Zuolin introduced Commedia dell'Arte structure but he chose to depict only the features which were 'suitable' to Chinese theatre. i.e. the use of masks, plot outline 
('canovaccio'), role types - or fixed role characters. In this illustration, Huang stressed elements that could be compared to Chinese traditional Opera.

He began with the illustration of mask structure (jia mianju xiju, 假面具喜剧) [2, p. 286]. Huang Zuolin stated that Italian improvised theatre masks differed from Chinese traditional Opera masks in one respect: the former were not facial make-up but real masks to be worn. He then explained a crucial point for understanding the acting method of Italian Commedia dell'arte, as wearing masks could be seen as a limit to the expressive ability of actors because the audience cannot see their facial expressions. Commedia dell'Arte actors relied on other means to convey their great expressive power - gestures and body movements gave characters a strong communicative power. Correctly balancing all these elements in the acting method was far more important than just facial expressions.

[。。］如果身体每一部分都有戏和面具配合起来，才有表现力 [。。。] 虽然面具是意大利即兴喜剧的特点, 但不是其根本特征, 也不是最本质最精华 部分。[2, p. 286]

[...] If each part of the body has the right coordination between mask and acting, therefore there is power of expression [...] Although masks are a distinguishing feature of Italian Commedia dellarte, it is not its fundamental characteristic, nor it is the most essential and intrinsic part of it.

There follows the analysis of the "canovaccio" system (or plot outline system) (mubiao $z h i$, 幕表制) [2, p. 286]: there was no real script but only a general outline with some indications about the main subject and lines. Actors had to rely on this plot outline and improvised their lines and performances. This system existed in ancient Chinese drama as well before the Yuan dynasty (1279-1368), when scholars began to write the first complex drama scripts called zaju (杂剧). At first, Chinese drama scripts were like an Italian 'canovaccio' and they were called huaben (话本). Chinese storytellers used huaben as plot outlines and as a support to memorize all the tales and stories in their repertory. Scholars state it is possible that in ancient times performances were totally improvised and stories were verbally transmitted, but, starting from the Song dynasty (960-1279) period, storytellers' performances spread in the so-called washe (瓦舍, entertainment district). Acting became a professional job, so the number of the stories grew as well and needed to be set out in writing. At first they were just notes, like the Italian plot-outlines, but they then gradually developed into real scripts. They actually had two different development paths: on the one hand they developed as written drama text, on the other hand they developed as short stories published in little pamphlets. This is why huaben is seen as the origin of both fiction and drama.

Huang Zuolin, in his article, shows some examples of Italian 'canovaccio':

“三个王八”-—三对夫妻。此夫追逐那妻, 那夫又追另妻, 大家不知, 而见面 时相互指骂: “你是王八!” $[2$, p. 287]

["Three cuckold" - Three couples of husbands and wives. This husband chases after that wife, that husband also chases after another wife, nobody knows and when they meet they curse each other: "You are a cuckold!"]

According to the source, Huang must have referred to the Italian scenario known as Li tre becchi [10, p.279]. Huang Zuolin only mentioned the main part of the canovaccio, 
the summary or "argument" at the beginning of each scene, whose function is to explain the main subject of the play. A summary was usually followed by general indications about the setting and actors' lines. It could be three or four pages in length.

The last aspect to be illustrated is the Italian role types or fixed-role characters, which in Italian are just called 'masks. This is the most important part of Huang Zuolin's speech because he made an interesting intercultural comparison - he attributed Chinese traditional Opera role names and characteristics to Italian improvised comedy characters. $\mathrm{He}$ stated that in Italian comic theatre every company usually had from twelve to fourteen actors and each one had “生、旦、净、末、丑等行档” (such major roles as sheng, dan, jing, mo, chou), exactly like Chinese Opera. We can view these words as a deliberate reading of the Italian cultural context through Chinese cultural standards in order to make the assimilation of a foreign system possible.

Huang Zuolin chose to depict some of them, starting from Pantaloon (潘塔龙 Pantalong) [2, p. 287]. Huang put this role inside the Chinese laosheng 老生 category. In Chinese Opera, this category included old or middle-aged male characters. They usually are respectable and decent men "but not necessarily men from high social classes" [11, p. 233]. Therefore, he described the Italian Commedia dell'arte character Pantalone as usually an "old or middle-aged man, a greedy merchant" [12, p. 82-85]. The actor needed some specific requirements to perform this character: first of all, he has to wear a mask with a Roman nose to emphasize his greed and then:

i. 必须精通威尼斯方言, 威尼斯是出商人的典型之地。

[He needs to be proficient in Venice dialect, Venice is the typical city of merchants]

ii. 必须对人老心不老的老朽、老混蛋能刻画得惟妙惟肖。

[He must be vividly depicted as a decrepit old bastard who is still young at heart]

iii. 必须在任何场合都能夸夸其谈 [。。。] 向少女求爱。

[He must be full of hot air in every occasion [...] run after young women]

iv. 必须对自己的愚蚌自以为是，老来少得使人发笑。

[He must foolishly believe himself infallible, old with young heart makes people laugh

v. 必须 [。。。] 见钱眼开, 爱才如命。[2, p. 288]

[He must be [...] thinking of nothing but personal gain and love money as much as life.]

Huang Zuolin put the role-character of the Doctor in the same Chinese theatre category of laosheng. As above, he described the doctor's characteristics: "He is a well-educated man, from the city of Bologna, a famous place of culture where there is the most ancient university in Europe. He speaks Bologna dialect and he can play the role of a scholar, a medical doctor, a lawyer, a philosopher or a theologian. He is pedantic and often quotes ancient Latin classics, he is a scholar without any practical skills, his long speeches are actually lacking real meaning and make him ridiculous and funny." [2, p. 288].

Huang made a brief description of the role of Captain and called this role "Spanish military official 西班牙军官 (Xibanya junguan)” [2, p.289].

Captain Maramoros' origins are not certain, but he is probably a type of scoundrel or bravo. This definition usually referred to a soldier of fortune, a mercenary from a foreign country. He usually was Spanish in order to make a parody of Spanish conquerors (Spain 
actually ruled many Italian kingdoms at that time in history). This arrogant character was more interested in collecting wealth for himself than thinking about people's welfare. He was skinny, irritable and wore a bright coloured costume, a plumed hat and a big sword. His language was a mixture of Italian, Spanish and French. He often fell in love with some young lady or caused trouble to lovers. According to different plays, he could have different names, e.g. Spaventa, Fracassa, Spezzaferro, Spaccamonte or Matamoros. This character fell into two main categories (each with many sub-categories), i.e. the Captain Spaventa type, who was a serious man, or the second role type, whose name usually was Matamoros and was definitely more comical [12, p. 90-92].

Huang only depicted the second one, Captain Matamoros, and probably made this "choice" for a specific purpose. To begin with, he specified his physical features, i.e. handsome, strong, with nice handlebar moustaches (nice, long, upward and curved, 漂亮的 胡子卷而翅, piàoliang de húzi juăn ér qiào) [2, p.289], a suit of armour and a high hat with feathers that resemble the open tail of a peacock (高帽子上插着翎子, 活像孔雀 开屏, gāo màozi shàng chā zhe língzi, huóxiàng kǒngquè kāi píng) [2, p.289]. He then focused on his arrogant personality, stating that he was a vain man who always tried to scare people with his sword but was essentially a good-for-nothing (是吹牛的大草包, shì chuīniú de dà căobāo) [2, p. 289].

Huang chose this role to show that, through this "negative" character, Commedia dell'Arte actors could make a satire of Spain's oppressive power over Italy. Huang wanted to show that comic play can be used to convey a serious content and it is possible to criticize a foreign nation's political oppressive power. Huang highlighted that, at the time, Spain was a powerful nation that had conquered many territories and oppressed people without giving them the opportunity to express their ideas:

因为当时西班牙是个侵略强国, 西班牙的军官目中无人、横行霸道, 人民敢怒 不敢言，所以创造这样一个人物来嘲笑。[2, p. 289]

[Because at the time Spain was an invader and a powerful nation, Spanish military officers were arrogant and domineering, people did not dare express their resentment, so the creation of such a character makes the audience laugh].

It is clear that Huang Zuolin chose to highlight this particular function of comic theatre because he wanted to suggest a new way (parody and jokes) to criticise invaders and oppressive European countries. Huang Zuolin saw a similarity with China's historical experience. Like Italy in the $16^{\text {th }}$ century, China had suffered the economic and territorial hegemony of some European countries in the $19^{\text {th }}$ and $20^{\text {th }}$ centuries and this was a very popular subject in Chinese theatre, literature and arts.

Huang gave the most important role in the Italian comic theatre to Harlequin, whom he called啊拉金诺 - Alajinnuo. He attributed to him the definition of main xiaochou (主要小丑 zhuyao xiaochou) [2, p.289], i.e. the "main clown" role in the Chinese Opera. There is probably a "misreading" of this role: Harlequin was not actually the main clown in Commedia dell'Arte but he was the second most important (second Zanni). The first Zanni, which means "clown", was Brighella, whom Huang put inside the Chinese role category of wuchou 武丑 [2, p. 291] and depicted as smart and as a "AhQ type-character" [2, p.291]. Huang did not mention other clowns of Commedia dell'Arte, such as the famous Pulcinella from Naples or the French Pierrot. There is apparently a reason behind this 
"mis-interpretation". In China, Harlequin had became much more popular than Brighella and other clowns thanks to Chinese performances of Goldoni's A Servant and two Masters (一仆二主Yi pu er zhu) and many important studies on Goldoni's theatre reform during the Forties and Fifties. This character was famous and appreciated not only for his similarity to Chinese chou but also for the important ideological meaning Chinese scholars attributed to him - he was a servant who finally rids himself of his masters. Goldoni gave the right importance to servants and common people in the development of plots and gave them a new psychological depth. Chinese scholars saw in Goldoni's reform something similar to the "revolutionary" change which Mao Zedong promoted in Chinese theatre. According to Tian Han, Mao said: "History is created by people but in ancient theatres ordinary people were depicted like 'scum' [...] our grandfathers and grandmothers, our sons and daughters must prevail on Chinese stages" [14, p. 5]. Huang Zuolin had a good knowledge of Chinese critique on Goldoni's theatre and, furthermore, found some analogies between the two characters, Harlequin and the chou, connecting Chinese tradition with the modern concept of theatre.

Harlequin and Chinese chou had common origins in that they are both clowns. In China, chou probably originated from court clowns during the Zhou dynasty called youling (优伶) or paiyou (俳优) [15, p. 4]. They probably are the first professional actors, even if they were bound to the court and were not economically independent. The Italian Harlequin probably originated from mime actors, clowns that performed pantomimes on the streets with colourful costumes and usually played the role of a servant or some rich man's assistant, who is always hungry and always tries to make money.

The second similarity is the comic function: both characters, chou and Harlequin, are important for their gags and jokes. The third is the type of character they acted. The Zanni role in the Commedia dell'Arte is of peasant origin, he is from the poor countryside around the town of Bergamo and he usually is a servant, a delivery man, a host or an innkeeper, a factotum. This was almost the same in Chinese chou: inside this category, there actually are many sub-categories: such as方巾丑 fangjin chou or 大丑 dachou, a man of letters, 官丑 guanchou or officials, 鞋皮丑 xiepi chou, a noble man or a “dandy”, but there also is the 茶衣丑 chayi chou category [15]. In this last one there are characters from the lower social classes, such as carpenters, cowhands, delivery men, hosts, innkeepers, exactly like the Italian Harlequin.

Huang Zuolin gave Harlequin an important role in comic theatre, arguing that his function is not only to make people laugh but also to be inspiring, in order to make people think about important topics such as history or social issues in a very cheerful manner. He focused on the importance of serious content and a deeper message in comedy, which gives the right value to the performance that is not just a set of gags and jokes:

虽然是假的, 但我们仍要很认真的把喜剧中的主题思想传达出来。喜剧中的主 题如同饭桌上的面包，而娱乐是饭桌上其他的东西，没有人愿意赴宴是为了去 吃面包, 宴会之所以吸引人是因为它有好酒、好菜和谈笑风生。但没有一个䇥 席不备面包的。喜剧也是同一道理, 来看喜剧的人不一定专为主题而来, 而是 为了寻找娱乐而来。[2, p. 300]

[Although it is fiction, we still want to seriously convey the idea of content inside comedy. The content of a comedy is like bread on the dining table and amusement is like the other things on the table, none want to attend a banquet in order to eat the bread, people 
are attracted by the banquet for the fine wine and food and for the cheerful atmosphere. But there is no banquet without bread. Comic theatre has the same principle: people who go to watch comedy do not go for the content but for amusement.]

In the final analysis, it is possible to argue that in his study of Italian Commedia dell'Arte Huang Zuolin emphasised what he believed to be most useful and attractive to Chinese theatre, that he adopted an "occidentalist" approach, as stated by Chen Xiaomei in her Occidentalism, a theory of counter-discourse in post-Mao China [6]. We can apply some of Chen's assertions about Occidentalism to this study: she argued that Chinese interest in Western culture products often has a specific final purpose that concerns China itself, it is an "appropriation of Western theories and practices [...] in order to produce new discourse, marked by a particular combination of Chinese construction of the West" $[6, p .2]$ with Chinese cultures or other elements because useful to Chinese discourse at that time. This consideration can help to understand Huang Zuolin's interpretation of Italian improvised theatre, which in some aspects appears the result of a partial understanding or a misunderstanding. Huang Zuolin actually selected, among the many aspects in the long and complex history of Italian Commedia dell'arte, what would be understandable, admissible but especially useful and valid to Chinese 'discourse'. He finally chose to emphasize a discourse in order to legitimate his creation of the "twelve rules" that would be the actual purpose for an evolution of Chinese comic theatre.

Huang Zuolin, choosing Commedia dell'Arte that is the symbol of the origin and the tradition of Italian theatre, aimed at proving that traditional theatre can be useful in the creation of new theatre forms and it needs to be considered an important source in the reform of contemporary Chinese theatre. At the same time, Huang illustrated that Italian theatre has some elements in common with Chinese traditional theatre in order to show not only that Italian Commedia dell'Arte can be assimilated into Chinese cultural context but that Chinese traditional culture, as well, can be used to create something new and valid in contemporary theatre.

\section{References}

1. Huang Z. 我与写意戏剧观: 佐临从艺六十年文选 Wo yu xieyi xiju guan: Zuolin cong yi liushi nian wenxuan [Me and my concept of xieyi theatre: a selection of sixty years' works of Zuolin]. Beijing, Zhongguo xiju chubanshe, $1990.574 \mathrm{p}$. (In Chinese)

2. 意大利即兴喜剧 Yidali jixing xiju [Italian improvised comic theatre]. 我与写意戏剧观: 佐临从艺 六十年文选 Wo yu xieyi xiju guan: Zuolin cong yi liushi nian wenxuan [Me and my concept of xieyi theatre: a selection of sixty years' works of Zuolin]. Huang Z. Beijing, Zhongguo xiju chubanshe, 1990, pp. 284-301. (In Chinese)

3. Huang Z. 意大利即兴喜剧 Yidali jixing xiju [Italian improvised comic theatre]. 《戏剧艺术》 Xiju yishu [Theatre Art], 1981, no.3, pp.34-44. (In Chinese)

4. Yu W. Tradizione e realtà del teatro cinese. Milano, International Cultural Exchange, 1995. $260 \mathrm{p}$.

5. Ferrari R. Da Madre Courage e i suoi figli a Jiang Qing e i suoi mariti, percorsi brechtiani in Cina. Venezia, Cafoscarina, 2004. 165 p.

6. Chen X. Occidentalism. A theory of counter-discourse in Post-Mao China. Second Edition, Revised and Expanded. New York and Oxford, Rowman and Littlefield Publishers, Inc. 2002. 257 p.

7. The Drama. A selective guide to Chinese literature 1900-1949. Ed. by B. Eberstein. Leiden, E. J. Brill, 1990, vol. 4.347 p.

8. Yu W. Sulle scene di Pechino. Goldoni vivo. Ed. by U. Ronfani. Roma, Presidenza del consiglio dei ministri, Dipartimento per l'informazione e l'editoria, 1994, pp. 202-208.

9. Mao Z. Discorsi alla conferenza di Yenan sulla letteratura e l'arte. Pechino, Casa editrice in lingue estere, $1968.46 \mathrm{p}$. 
10. La commedia dellarte: storia e testo. Ed. by V.Pandolfi. Firenze, Sansoni Antiquariato, 1959, vol. 5 . $442 \mathrm{p}$.

11. Pisu R., Tomiyama H. L'Opera di Pechino. Milano, Mondadori, 1982. 237 p.

12. Maschere italiane: $i$ volti della commedia dellarte! Firenze, Demetra, 2002. $127 \mathrm{p}$.

13. Di Nallo I. Gli studi goldoniani in Cina alla metà del XX secolo. Linguce \& - Rivista di lingue e culture modern, 2016, no. 15 (2016) 1, pp. 43-64.

14. Tian $\mathrm{H}$. 我们要健康的, 战斗的笑！我们要哥尔多尼！在世界文化名人卡尔罗·哥尔多尼诞 辰250周年纪念会上的发言 Women yao jiankang de, zhandou de xiao! Women yao Geerduoni! Zai shijie wenhua mingren Kaerluo Geerduoni danchen 250 zhounian jinian hui shang de fayan [We want healthy laughs, laughs of fight! We want Goldoni! Speech delivered at the World Literary Conference for the $250^{\text {th }}$ anniversary of the birth of the famous Carlo Goldoni]. 《文艺报》Wen yi bao [Art and Literature], 1957, no. 27, pp. 4-5. (In Chinese)

15. Li D. 丑角 Chou jiao [The clown]. Tianjin, Baihua wenyi chubanshe, 2007. 215 p. (In Chinese)

For citation: Di Nallo I. Huang Zuolin and Italian Commedia dell'Arte: an experimental study in the conception of Xieyi theatre. Vestnik SPbSU. Asian and African Studies, 2017, vol.9, issue 1, pp. 29-40. DOI: $10.21638 / 11701 /$ spbu13.2017.103.

Статья поступила в редакцию 12 октября 2016 г. Статья рекомендована в печать 24 ноября 2016 г.

Контактная информация

Ileana Di Nallo _ PhD; ileana.dinallo@uniurb.it

Илеана Ди Налло - PhD; ileana.dinallo@uniurb.it 